\title{
Phialomyces macrosporus REDUCES Cercospora coffeicola SURVIVAL ON SYMPTOMATIC COFFEE LEAVES
}

\author{
Marie Caroline Ferreira Laborde ${ }^{1}$, Deila Magna dos Santos Botelho², \\ Gabriel Alfonso Alvarez Rodríguez ${ }^{3}$, Mário Lúcio Vilela de Resende ${ }^{4}$, Marisa Vieira de Queiroz ${ }^{5}$, \\ Aline Duarte Batista ${ }^{6}$, Patrícia Gomes Cardoso 7 , Sérgio Florentino Pascholati ${ }^{8}$, \\ Luis Fernando Pascholati Gusmão ${ }^{9}$, Samuel Júlio Martins ${ }^{10}$, Flávio Henrique Vasconcelos de Medeiros ${ }^{11}$
}

(Received: March 06, 2018; accepted: December 11, 2018)

\begin{abstract}
Brown eye spot is among the most important coffee diseases, it is caused by a necrotrophic fungal Cercospora coffeicola. Saprobe fungi have potential in reducing the survival of necrotrophic pathogens and can act through competition of nutrients, mycoparasitism, antibiosis and resistance induction. We have screened saprobe fungi for the ability to reduce C. coffeicola sporulation and viability and determined the possible mechanisms involved in the biocontrol. The selected saprobe fungus, Phialomyces macrosporus, reduced the germination of C. coffeicola conidia by $40 \%$. P. macrosporus produced both volatile and non-volatile compounds that inhibited $C$. coffeicola growth, sporulation and viability. The production of antimicrobial substances was the main mode of action used by the saprobe fungi. Therefore, P. macrosporus is a promising biological agent for the integrated management of brown eye spot.
\end{abstract}

Index terms: Coffea arabica, competition, biological control, brown eye spot, antibiosis.

\section{Phialomyces macrosporus REDUZ A SOBREVIVÊNCIA DE Cercospora coffeicola EM FOLHAS DE CAFÉ SINTOMÁTICAS}

\begin{abstract}
RESUMO: A cercosporiose é uma das mais importantes doenças do cafeeiro e tem como agente etiológico o fungo necrotrófico Cercospora coffeicola. Os fungos sapróbicos têm potencial na redução da sobrevivência de patógenos necrotróficos e podem atuar por meio da competição de nutrientes, micoparasitismo, antibiose e indução de resistência. Nós selecionamos fungos sapróbios para a capacidade de reduzir a esporulação e viabilidade de C. coffeicola e determinamos os possíveis mecanismos envolvidos no biocontrole. O fungo saprobio selecionado, Phialomyces macrosporus, reduziu a germinação de conídios de C. coffeicola em $40 \%$. P. macrosporus produziu compostos voláteis e não voláteis que inibiram o crescimento, esporulação e viabilidade de $C$. coffeicola. A produção de substâncias antimicrobianas foi o principal modo de ação utilizado pelos fungos sapróbicos. Portanto, P. macrosporus é um potencial agente biológico que pode ser usado no manejo da cercosporiose do cafeeiro.
\end{abstract}

Termos para a indexação: Coffea arabica, competição, controle biológico, mancha de olho pardo, antibiose.

\section{INTRODUCTION}

Coffee (Coffea arabica L.) is an important commodity worldwide. However, diseases are responsible for many losses in this crop. Brown eye spot (BES), caused by the necrotrophic fungus Cercospora coffeicola Berkeley \& Cooke is considered one of the most important coffee diseases and affects both leaves and berries, causing yield losses of approximately 50\% (Zambolim et al., 2016).
Although effective fungicide-based alternatives are available for the disease management (Patricio et al., 2008), it should not be the exclusive tool but part of the integrated brown eye spot management such as plant nutrition (Cardoso et al., 2013) and biological control (Sirinunta and Akarapsan, 2015).

Considering that conidia of $C$. coffeicola remain viable for up to nine months in coffee stubble (Zhang and Bradley, 2014) until favorable

\footnotetext{
1,2,3,4,11 Universidade Federal de Lavras/UFLA - Departamento de Fitopatologia/DFP - CX. P. 3037 - 37.200-000 - Lavras - MG marielaborde89@hotmail.com, deilamagna@hotmail.com, galvarez_rodriguez@hotmail.com, mlucio@dfp.ufla.br, flaviomedeiros@dfp.ufla.br

${ }^{5,6}$ Universidade Federal de Viçosa/UFV - Departamento de Microbiologia - Av. PH Holfs, sn - 36.570-000 -Viçosa - MG mvqueiro@hotmail.com, aline.batista@ufv.br

${ }^{7}$ Universidade Federal de Lavras/UFLA - Departmento de Biologia/DBI - Cx.P. 3037 - 37.200-000 - Lavras - MG patricia@dbi.ufla.br

${ }^{8}$ Escola Superior de Agricultura Luiz de Queiroz - Universidade de São Paulo - Departamento de Fitopatologia e Nematologia Avenida Pádua Dias, 11 - 13.418-900 - Piracicaba - SP - sfpascho@usp.br

${ }^{9}$ Universidade Estadual de Feira de Santana - Departamento de Ciências Biológicas - Av. Transnordestina, s/n - 44.036-900 Feira de Santana - BA - lgusmao.uefs@gmail.com

${ }^{10}$ Department of Plant Pathology and Environmental Microbiology - Pennsylvania State University - University Park, PA 16802

Estados Unidos da América. samueljmt@yahoo.com.br
} 
conditions for germination, the reduction of the initial inoculum should be taken into account as a strategy for the integrated management of the disease. This can be achieved by compostaccelerating products which encompasses both fast-growing fungi and cell wall degrading enzymes (Bellotte et al., 2009; Hauptman, 2014).

Because $C$. coffeicola is a necrotrophic fungus, its suppression by microbial antagonists may occur through a combination of mechanisms, such as the production of antimicrobial compounds, mycoparasitism and/or competition for nutrients. Competition for nutrients is likely to occur since hydrolytic enzymes produced by both pathogen and antagonist target the saprophytic survival on decaying leaves (Jurado et al., 2015; Alvarez-Rodriguez et al., 2016). Among these enzymes are pectinases, which are composed by an heterogeneous group of enzymes that degrades pectin (Falmy et al., 2008).

One such pectinase producers group are saprobic fungi. They play a significant role in the self- maintenance of a balanced ecosystem, mostly through the decomposition of organic matter, using a system of digestive enzymes that are secreted from the cells to the environment (Lin et al., 2015). Furthermore, they can withstand sudden variations in temperature and humidity and sustain biological control in such environment, which turn them promising biological control agents (Köhl et al., 1995). Currently, saprobe fungi have been used as a biological agent for coffee disease control (Botrel et al., 2018; Rodríguez et al.,2016). Therefore, we hypothesize that saprobe fungi might inhibit $C$. coffeicola growth in crop residues and its production antifungal compounds and cell-wall degrading enzyme may play a role in the pathogen displacement.

\section{MATERIALS AND METHODS}

\subsection{Culture condition}

The isolate LFP 37 of Cercospora coffeicola was obtained from the Culture Collection of Cercospora coffeicola at the Plant Pathology Department, Federal University of Lavras, Minas Gerais State, Brazil. Isolate LFP 37 was grown for 10 days on solid V8 medium (V8S) ( $200 \mathrm{~mL}$ of V8 juice, $800 \mathrm{~mL}$ of distilled water and $20 \mathrm{~g}$ of agar) at $25^{\circ} \mathrm{C}$. A modified version of the methodology proposed by Souza et al. (2005) was used to sporulate the isolate LFP 37 . The pathogen spore suspension was adjusted to $3 \times 10^{4}$ conidia $\mathrm{mL}^{-1}$.
Three saprobe fungal strains were used in this study: Phialomyces macrospores (0053/07), Curvularia inaequalis (0005/06), and Curvularia eragrostidis (0047/06), obtained from the Culture Collection of the Microorganisms from Bahia, State University of Feira de Santana, Bahia, Brazil.

The strains were grown for 7 days in a medium of carrot maize agar (CMA) at $27^{\circ} \mathrm{C}$. After incubation, one disk $(7 \mathrm{~mm})$ containing conidia and mycelium was suspended in 100 $\mathrm{mL}$ of $\mathrm{CM}$ liquid medium, grown in an orbital shaker at $120 \mathrm{rpm}$ and $27^{\circ} \mathrm{C}$. The suspension was shredded, homogenized in a blender, and adjusted to $3.4 \times 10^{7} \mathrm{CFU} \mathrm{x} \mathrm{mL} \mathrm{m}^{-1}$. Antagonistic fungi were inoculated by spraying the leaves until runoff, unless otherwise stated.

\subsection{Coffee seedlings}

Coffee seeds (Cultivar Mundo Novo IAC 376-4) were purchased from Agricultural Research Company of Minas Gerais (EPAMIG) and were seeded in plastic trays containing white sand for pre-germination. Two-month old seedlings were transferred to polyethylene bags $(250 \times 90 \mathrm{~mm})$ filled with substrate made from a dystroferric Red Latosol $\left(700 \mathrm{~L} \mathrm{~m}^{-3}\right)$ taken from a gully, and fertilize was by the addition of natural phosphate $(5 \mathrm{~kg} \mathrm{~m}-3)$ and potassium sulfate $(0.5$ $\mathrm{kg} \mathrm{m}^{-3}$ ) (MATIELLO et al., 2010). Plants were kept in a greenhouse at $25^{\circ} \mathrm{C}-28^{\circ} \mathrm{C}$ during the entire experiment.

\subsection{Screening test}

Pathogen inoculation consisted of spraying the inoculum suspension on the abaxial side of the coffee leaves (7-month-old) until runoff. Dark wet plastic bags were placed during 3 days to simulate a moist micro-chamber. At 15 days after inoculation (dai), when BES symptoms appeared, the three abovementioned antagonists were sprayed onto the leaves until runoff. Soil $\operatorname{Set}{ }\left(0.75 \mathrm{~mL} \mathrm{~L}^{-1}\right)$ associated with compost Aid $\AA$ $\left(0.75 \mathrm{~mL} \mathrm{~L}^{-1}\right)$ were used as positive control, as described by Bellotte et al. (2009). Distilled water was applied as a negative control. After saprobe application, 10 leaves from each treatment were stored in plastic bags at $28^{\circ} \mathrm{C}$ for 7 and $14 \mathrm{~d}$. Number and germination of LFP 37 conidia were determined.

To determine the number of conidia, lesions of each leaf were excised and transferred to $10 \mathrm{~mL}$ tubes with $1 \mathrm{~mL}$ of distilled water with $300 \mu \mathrm{L}$ of Tween $20 \%(\mathrm{v} / \mathrm{v})$. Aliquots of each suspension 
were counted using a haemocytometer. For the viability spore test, a $400 \mu \mathrm{L}$ aliquot of the suspension of each treatment was transferred to $90 \mathrm{~mm}$ Petri dishes containing $15 \mathrm{~mL}$ of water-agar at $2 \%(\mathrm{w} / \mathrm{v})$. The plates were incubated at $25^{\circ} \mathrm{C}$ for $6 \mathrm{~h}$, and the number of germinated spores was counted under light microscope at $40 \times$. Conidia were considered germinated when the germ tube was equal to or greater than half of the spore length (Beckman and Payne, 1983). The experiment was performed twice, and the fungus with the highest potential to reduce pathogen survival was selected to continue the study. The experimental design was a randomized block with five treatments (C. inaequalis, C. eragrostidis, P. macrosporus, Compost Aid+ Soil Set and water), five plants per experimental unit and three replications.

\subsection{Assessment of antagonist drought- tolerance}

Drought tolerance was assessed to study the ability of $P$. macrosporus to reduce $C$. coffeicola isolate LFP 37 survival in plant lesions under humidity variation to simulate field conditions (Köhl etal., 1995). Fungal growth, plantcultivation, and fungal spray were performed as described above. Immediately after antagonist application, wetness was interrupted. Thereafter, 10 leaves per treatment were placed on two layers of sterile dry filter paper in open Petri dishes in laminar flow cabinet for $9 \mathrm{~h}$. The leaves were incubated for two different periods of interrupted wetness $(0$ and $61 \mathrm{~h}$ ) after the antagonist application. (Köhl et al.,1995). After the dry period, the filter paper was wetted with $2 \mathrm{~mL}$ of sterile tap water. Then, the Petri dishes were closed and kept under the same conditions, as described above. After 7 days, number and germination of pathogen conidia were determined, as previously described. The experiment was set up in a completely randomized block design, using a factorial scheme $(1 \times 2)$ with P.macrosporus fungus and two different periods of interrupted wetness $(0$ and $61 \mathrm{~h})$. Each treatment was represented by three replicates and each replicate was composed with 10 leaves per plot.

\subsection{Antibiosis and volatile production test}

A method of measuring the direct activity of antagonists against pathogens was used in the in vitro antibiosis and volatile production test (Prasad et al., 2011). These assays were performed by cultivating the fungi on regular and bipartite Petri for antibiosis and volatile production, respectively.
The putative ability of $P$. macrosporus to produce different molecules or enzyme toxic to the pathogen was assessed by the confrontation assay. Plates were incubated at $25^{\circ} \mathrm{C}$ and $12 \mathrm{~h}$ in the light for 5 days. The assay was evaluated by cultivating P. macrosporus on one side of the Petri dish and C. coffeicola on the opposite side. The fungi were cultivated on Potato Dextrose Agar (PDA, $39 \mathrm{~g}$ $\mathrm{L}^{-1}$ ), CMA and V8 media. The negative control contained only the pathogen in one side of the plates. The effect of toxic molecules or enzyme produced by $P$. macrosporus on C. coffeicola was quantified by comparing the mycelia growth and number of conidia. The experiment was distributed in a randomized block design with four replicates and was performed twice.

The production of fungitoxic volatiles compounds by $P$. macrosporus was evaluated by cultivating $P$. macrosporus in one side of a bipartite Petri and C. coffeicola in the opposite side. Plates were incubated at $25^{\circ} \mathrm{C}$ and $12 \mathrm{~h}$ in the light for 5 days. Saprobe fungi were cultivated on PDA, CMA and V8. The negative control contained only the pathogen in one side of the plates. The effect of fungitoxic volatiles compounds by $P$. macrosporus on $C$. coffeicola was quantified by comparing the mycelial growth, number and germination (\%) of conidia. The experiment was distributed in a randomized block design with four replicates and was performed twice.

\subsection{Pectinase production}

The ability to produce hydrolytic enzyme in solid medium was assessed by growing $P$. macrosporus on mineral medium ( $\mathrm{pH} 7.2)(2.0 \mathrm{~g}$ $\mathrm{L}^{-1} \mathrm{KH}_{2} \mathrm{PO}_{4} ; 7.0 \mathrm{~g} \mathrm{~L}^{-1} \mathrm{~K}_{2} \mathrm{HPO}_{4} ; 1.0 \mathrm{~g} \mathrm{~L}^{-1}\left(\mathrm{NH}_{4}\right) 2 \mathrm{SO}_{4}$; $1.0 \mathrm{~g} \mathrm{~L}^{-1} \mathrm{MgSO}_{4} \cdot 7 \mathrm{H}_{2} \mathrm{O}$; yeast extract $0.06 \%(\mathrm{p} / \mathrm{v})$; and $13 \mathrm{~g} \mathrm{~L}^{-1}$ agar). The medium was supplemented with $3 \mathrm{~g} \mathrm{~L}^{-1}$ citrus pectin and incubated at $27^{\circ} \mathrm{C}$ for 5 days. Agar discs ( $7 \mathrm{~mm}$ diameter) containing mycelia from the colonies were transferred to Mac McIlvaine buffer $\left(0.2 \mathrm{M} \mathrm{NaHPO}_{4}, 0.1 \mathrm{M}\right.$ citric acid, $13 \mathrm{~g} \mathrm{~L}^{-1}$ agar-pH 6.0 ) with $0.25 \%(\mathrm{w} / \mathrm{v})$ citrus pectin and incubated at $40^{\circ} \mathrm{C}$ for $48 \mathrm{~h}$. A solution of I2/KI ( $1 \mathrm{~g}$ of I2 and $5 \mathrm{~g}$ of $\mathrm{KI}$ in $330 \mathrm{~mL}$ of $\mathrm{H}_{2} \mathrm{O}$ ) was added to detect the clearing zones.

\subsection{Fungal cultivation for Polygalacturonase (PG) assays}

P. macrosporus was cultivated on solid minimum medium containing $6,0 \mathrm{~g} \mathrm{~L}^{-1} \mathrm{NaNO}_{3}$; $1,5 \mathrm{~g} \mathrm{~L}^{-1} \mathrm{KH}_{2} \mathrm{PO}_{4} ; 0,5 \mathrm{~g} \mathrm{~L}^{-1} \mathrm{KCL} ; 0,5 \mathrm{~g} \mathrm{~L}^{-1}$ $\mathrm{MgSO}_{4} .7 \mathrm{H}_{2} \mathrm{O} ; 0,01 \mathrm{~g} \mathrm{~L}^{-1} \mathrm{FeSO}_{4} ; 0,01 \mathrm{~g} \mathrm{~L}^{-1} \mathrm{ZnSO}^{2}$; 
$10,0 \mathrm{~g} \mathrm{~L}^{-1}$ glucose; $15 \mathrm{~g} \mathrm{~L}^{-1}$ agar at $6,8 \mathrm{pH}$ for $7 \mathrm{~d}$, to a final concentration of $10^{6}$ espores $\mathrm{mL}^{-1}$. Then, one disk $(7 \mathrm{~mm})$ containing conidia and mycelium was inoculated into erlenmeyer flasks $(125 \mathrm{~mL})$ containing $50 \mathrm{~mL}$ of liquid mineral medium $(6.8$

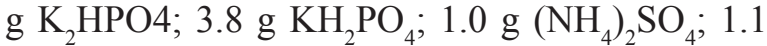
g $\mathrm{MgSO}_{4} .7 \mathrm{H}_{2} \mathrm{O} ; 0.6 \mathrm{~g}$ yeast extract, $3 \mathrm{~g}$ pectin $2 \%$ in one litter of distilled water) with one disk $(7 \mathrm{~mm})$ of mycelium and shaken at $150 \mathrm{rpm}$ at $27^{\circ} \mathrm{C}$ for 5 days. The culture filtrates were used to directly estimate PG activity and the mycelia were collected daily to quantify total mycelial dry mass.

\subsection{Assessment of Fungal growth and PG activity}

The fungal growth was quantified by dry weight for 5 days. For this, the mycelium was collected by filtration through nylon cloth under vacuum and dried at $60^{\circ} \mathrm{C}$ for $48 \mathrm{~h}$. The dried mycelium mass was measured using a precision balance (0.01 g precision).

The PG activity was determined by mixing 1 $\mathrm{mL}$ of culture filtrate in $1 \mathrm{~mL}$ of substrate solution (100 mM sodium acetate buffer; [ $\mathrm{pH} 4.5] ; 0.2$ $\mathrm{mM} \mathrm{NaCl}, 1.2 \%$ polygalacturonic acid $[\mathrm{w} / \mathrm{v}]$ ) and incubated at $40^{\circ} \mathrm{C}$ for $20 \mathrm{~min}$. The reducing sugars released in the medium were measured by using the 3.5-dinitrosalicylic acid methods with galacturonic acid as a control. One PG unit was defined as micromoles of galacturonic acid released per minute per millilitre.

\subsection{Assessment of each fungal derivate to pathogen viability reduction}

To determine the ability of each fungalderived product or enzyme to displace the pathogen from lesions were carried out in vitro and in vivo assays. For the in vitro assay, coffee leaf samples naturally infected by isolate LFP 37 were collected from field-grown fungicide-free plants. The leaves were distributed in a randomizedblock design with four replicates and five to eight injured leaves per treatment per plot. Treatments were: i) water; ii) Conidia suspension $\left(10^{6}\right.$ spores $\mathrm{mL}^{-1}$ ) of $P$. macrosporus; iii) polygalacturonase enzyme produced by the saprobe iv) conidia +supernatant of the saprobe and v) the supernatant of the saprobe growth.

In every case, the fungi were grown for the previously determined minimum time necessary for the maximum activity of polygalacturonase, 120 hours. After 7 days of incubation, the number of conidia of LFP 37 and leaf weight were assessed.
For the in vivo assay, coffee seedlings cv. 'Mundo Novo IAC 376-4' were inoculated with isolate LFP 37 and from the onset of symptoms (25 dai), each fungal-derived product or enzyme mentioned above was sprayed onto the leaves until runoff. Then, 10 leaves from each treatment were used to determine the pathogen conidia count and initial germination. After 7 days of incubation, the number and final germination of conidia were assessed. The plants were distributed in a randomized-block design with four replicates and one seedling per plot. The treatments were the same used for the in vitro assay. The in vivo assay was performed twice.

\subsection{Experimental design and statistical analysis}

Data from different experiments were tested for normality and submitted to an analysis of variance (ANOVA), Tukey and Scott-Knott multiple range tests $(P=0.05)$. Data related to Polygalacturonase activity and dry mycelial weight of $P$. macrosporus were submitted to regression equations and subjected to a parallelism (F-test) test. The goodness of fit of the models was evaluated by coefficient of determination $\left(\mathrm{R}^{2}\right)$. Data analysis was performed in the $\mathrm{R}$ software version 3.1.1.

\section{RESULTS AND DISCUSSION}

To the best of our knowledge, for the first time a biological control option for BES targeted its saprophytic phase was best achieved by the use of P. macroscopus (Figure 1). In the screening assay, there was no significant interaction between the treatments and the time when the experiment was carried out for either the conidia count $(\mathrm{P}=0.46)$ or the viability of LFP 37 conidia $(\mathrm{P}=0.14)$. Regarding LFP 37 conidial germination, these in vivo assays showed that the application of $P$. macrosporus to the injuries caused by the pathogen reduced the viability of LFP 37 by $40 \%$ in 7 days ( $\mathrm{P}=0.0003$ ) (Figure 1 ). This effect persisted for at least 14 days after application of the antagonist under study (Figure 1), showing that not only the saprobe was able to reduce the viability of the pathogen, but this effect also occurs at the earliest considered time point (7 days after treatment). Odile-Mathieu and David Daniel (2006) studied isolates of Microsphaeropsis ochracea in the lesions of onion leaves during senescence and reported a reduction in the sporulation of Botrytis squamosa from 10 days after the application of the antagonist. 


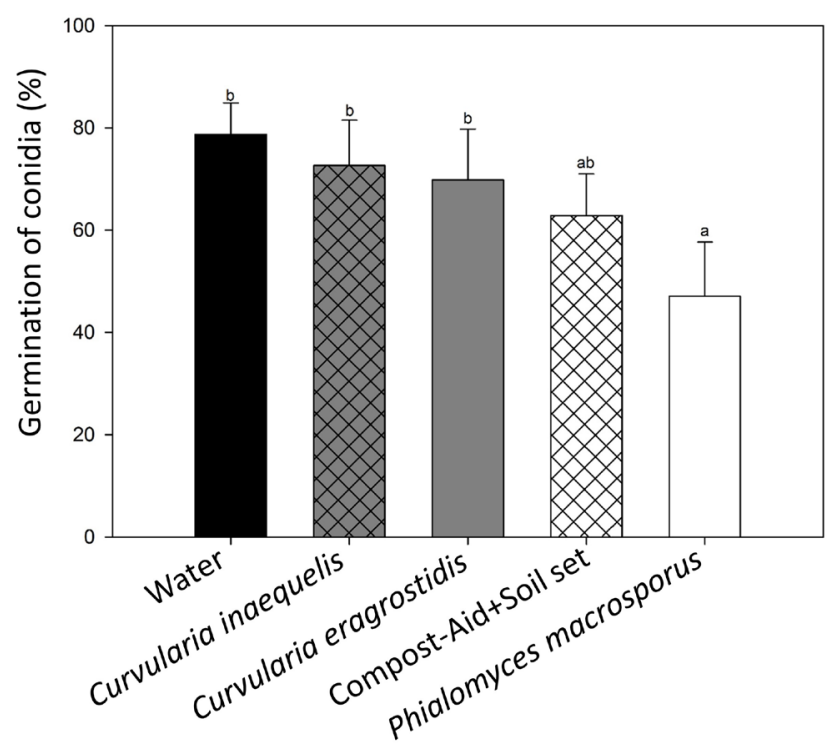

FIGURE 1 - Germination of Cercospora coffeicola conidia evaluated at 0, 7, and 14 days after the application of water, Curvularia inaequelis, Curvularia eragrostidis, Compost-Aid+Soil set and Phialomyces macrosporus. Bars with the same letter are similar at the $5 \%$ level according to Tukey multiple range test. $\mathrm{CV}=24.85 \%$. The line on each bar represents \pm SE.

In our study, the contribution of the reduced inoculum of Cercospora to the occurrence of BES in the field was not evaluated, but a similar study by Galletti et al (2008) showed that when Trichoderma sp. was applied to the leaves of sugar beet infected with Cercospora beticola, the viability of the pathogen spores decreased, resulting in a delay of the epidemic in the subsequent crop.

The performance of antagonists under field conditions is determined mainly by their ecological competence. Regardless water stress condition $(P=0.82$ and $P=0.95)$, there was a reduction of conidial viability of up to $37.72 \%$. This result is in agreement with Köhl et al. (1995), who showed suppression of sporulation of Botrytis aclada in dead onion tissue treated with the antagonist Ulocladium atrum in bioassays with repeated wet-dry-cycles. In addition to evaluating the potential of the saprobe to control the pathogen regardless of the stress to which it is exposed, which aims to determine the sustainability of the control technique, it is necessary to evaluate the action mechanisms of the biocontrol agent. One of the most common mechanisms of reduced survival of pathogens is antibiosis. Hiradate et al. (2002) observed a decrease in the survival of Colletotrichum dematium on mulberry leaves infected when treated with Bacillus amyloliquefaciens, confirming that the production of antifungal compounds was the primary mechanism of action that was used by the antagonists under study.

For the antibiosis test, interaction was observed between medium and treatments $(P=0.0090)$. A positive interaction was observed between culture media CMA $(P=0.0018)$, V8 $(P=\leq 0.001)$, and production of non-volatile compounds, resulting in greater pathogen control (Figures 2 and 3).

Reduction in the mycelium growth, sporulation and spore germination was observed when C. coffeicola was cultured in the presence of the P. macrosporus (Figure $4 \mathrm{~A}, \mathrm{~B}$ e C). Thus, it is suggested that such culture media induce the production of a greater amount or range of compounds with an inhibitory action on isolate LFP 37 .Similar result was obtained by Abe et al. (2015) who isolated a class of secondary metabolites, polyketides from the fungus $P$. macrosporus, which is known to provide survival advantages to microbial hosts. Some of the benefits could be the production of antibiotics, as reported by Zhang et al. (2015) who studied the antibiosis functions during interactions of Trichoderma spp. with plant pathogenic Rhizoctonia and Pythium. The authors confirmed that polyketide positively correlated to the production of antibiotics. 


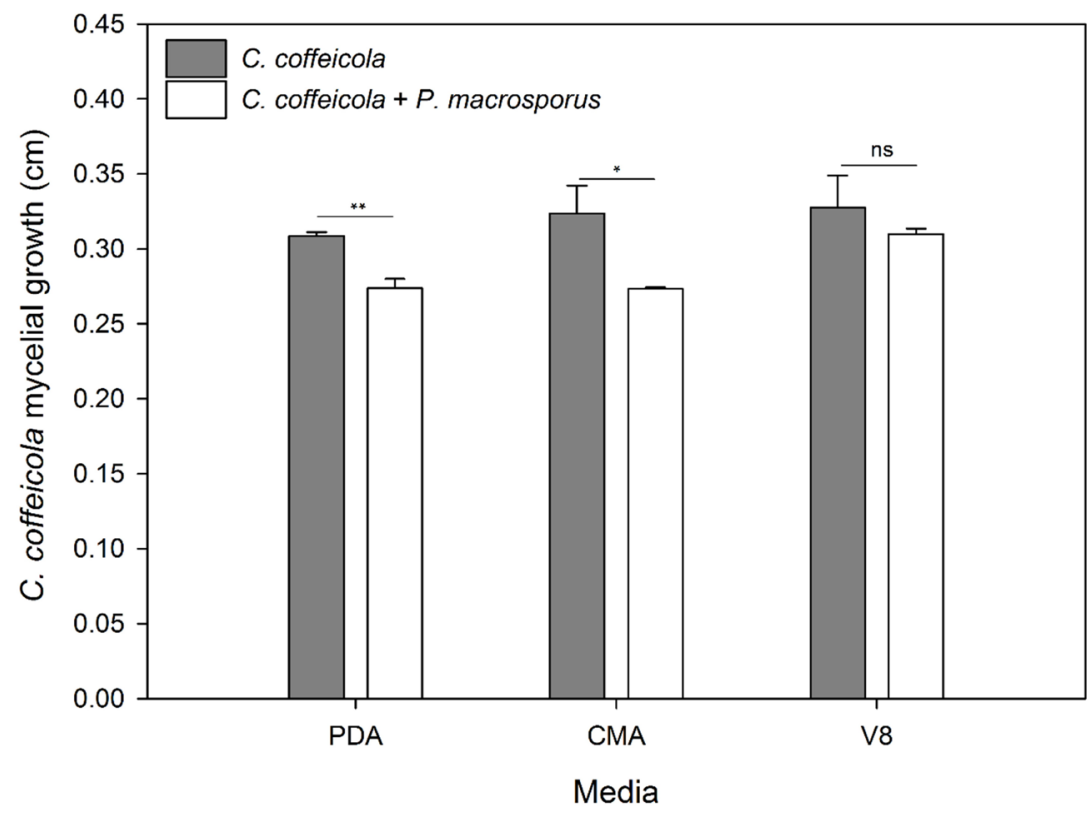

FIGURE 2 - Cercospora. coffeicola mycelial growth in confrontation test against P. macrosporus on PDA, CMA, and V8 media. Related graphic analysis of the unfolding of the treatments $(C$. coffeicola and $C$. coffeicola $+P$.

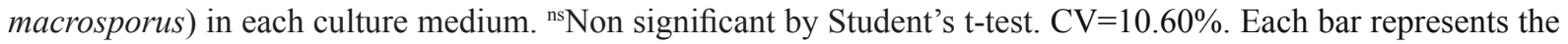
mean of four replicates (Petri dishes) per treatment per culture medium.

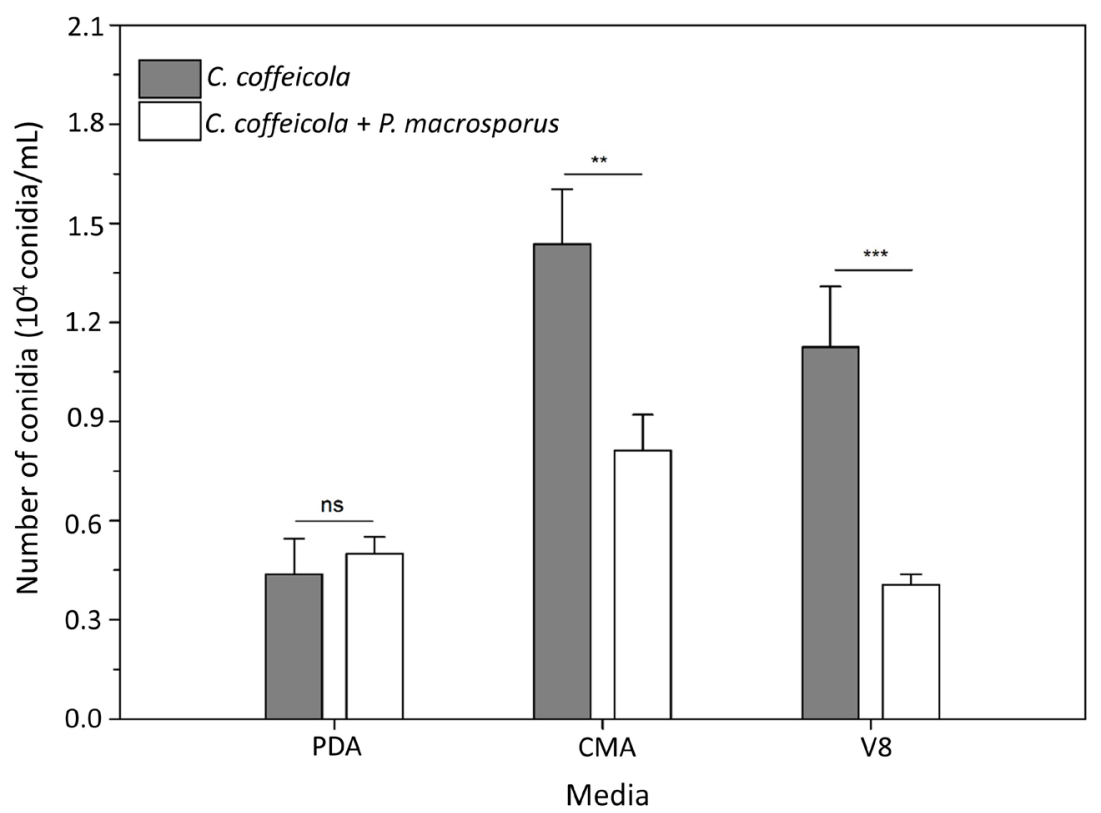

FIGURE 3 - Number of conidia of Cercospora coffeicola in volatile test against $P$. macrosporus on PDA, CMA, and V8 media. Graphic analysis of the unfolding of the treatments (C. coffeicola and C. coffeicola + P. macrosporus) within each culture medium. Significantly different according to the Student's t-test ${ }^{* *}(P \leq 0.01)$ or ${ }^{* * *}(P \leq 0.001)$.

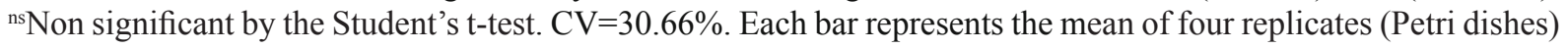
per treatment per culture medium. 
Laborde, M. C. F. et al.

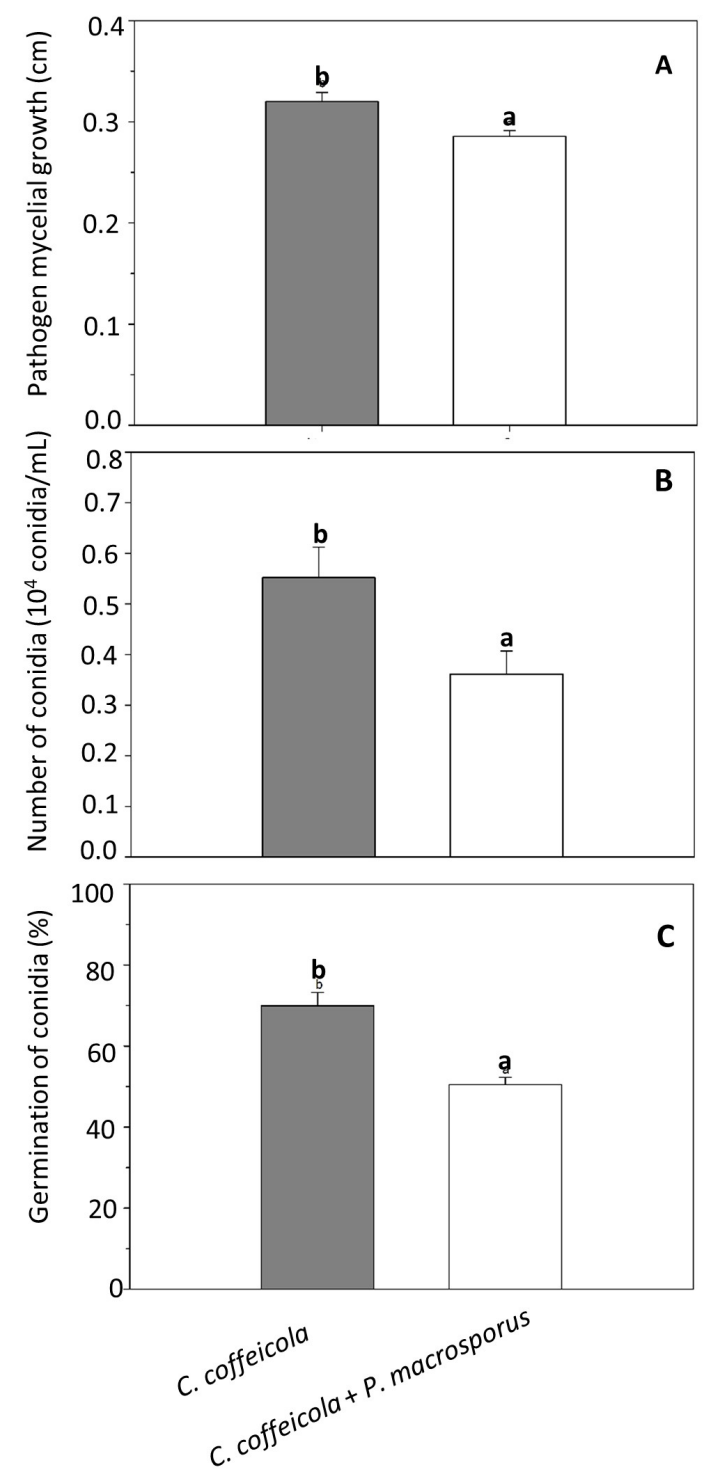

FIGURE 4 - Effect of volatile production by Phialomyces macrosporus on mycelium growth (A), sporulation (B) and spore germination (C) of Cercospora. coffeicola. The bars with the same letter are similar at the $5 \%$ level according to the Student's t-test $(P \leq 0.05)$. $C V=13.23 \%, 39.11 \%$, and $7.80 \%$ for graphs $\mathrm{A}, \mathrm{B}$, and $\mathrm{C}$, respectively. The line on each bar represents \pm SE.

The largest dry micelial weight was observed at 120 hours (Figure $5 \mathrm{~A}$ ). The enzymatic activity of PG, detected in the culture supernatant, showed a gradual increase over the growing time, with the highest activity in 120 hours (Figure 5B).The competition mechanism between microorganisms in a settling necrotic area was tested by determining and quantifying pectinolytic enzymes. These enzymes degrade dead plant tissue and release nutrients for both the pathogen and saprobe. Thrane et al. (2000) monitored GFP- tagged Trichoderma spp. saprobes in cucumber plants infected with Pythium ultimum and found that the biocontrol isolates were able to take up the nutrients in the plant tissue more efficiently than was the pathogen, confirming that competition for nutrients is an important mechanism in this biocontrol pathosystem. Rodríguez et al. (2016) recently confirmed this hypothesis by determining that the niche overlap index between P. macroscoporus and Colletotrichum gloeosporioides was $100 \%$, i.e., all nutrients the 
pathogen uses, the biocontrol agent also does and surviving in the necrotrophic tissue provoked by the pathogen.

Furthermore, in addition to externally colonizing plants, one important feature of fungi is the colonization of live plant organs and exerting benefits to the plant over the long term (Barahona et al., 2011). Reports by Ahmad et al. (2003) showed that P. macrosporus colonizes coffee berries of robusta and arabica. Therefore, similar to Cladosporium cladosporioides isolates, P. macrosporus growth may acts as a barrier to the entry of other harmful fungi quality of coffee. Furthermore, C. cladosporioides is characterized as a saprophyte fungus and PG enzyme producer (Rezende et al., 2013).

In this study, we identified the production of PG on solid medium through the formation of the corresponding halo enzyme production. The average diameter of the formed halo was $0.93 \mathrm{~cm}$. However, when we compared the $P$. macrosporus activity of PG $(744.2685 \mathrm{U} / \mathrm{mL})$ with microorganisms that have the ability to secrete large amounts of this protein, such as Penicillium griseoroseum $(1600 \mathrm{U} / \mathrm{mL})$, we cannot consider this saprobe a significant PG producer (Minussi et al. 1998).

Although, we suggest a synergistic activity of this enzyme and antibiosis act on the pathogen displacement from the lesion hence in reduction of its survival on detached leaves and in vivo test. Further studies are necessary to investigate the role of PG in the observed biocontrol.
Contribution of each fungal derivate, such as conidia and any metabolite, in reducing the number of pathogen conidia and lesion degradation were evaluated by in vitro and in vivo assays. From the in vitro experiment, this supernatant was not effective in the degradation of lesion tissue in the short-term evaluation (7 days after treatment) $(P=0.91)$, suggesting longer cultivation time to achieve a significant decrease in weight of leaf and therefore treatment effectiveness. Additionally, there was no difference between the treatments for the number of conidia of LFP $37(P=0.44)$. On the other hand, $P$. macrosporus consistently reduced LFP 37 conidia viability in detached leaves and in coffee plants. For the in vivo assay, not only the conidia of the saprobe fungus but also all of the fungal-derived products or enzymes reduced the germination rate by $40 \%(P=0.00003$ and 0.00$)$ (Figure 6).

Since there was no significant difference between these treatments, either one could be used as a control, which gives more versatility to the use of this fungus as a future biological product. In addition, other authors have reported the use of $P$. macrosporus as a biocontrol agent in coffee diseases. Botrel et al. (2018) observed a reduction in the severity of coffee halo blight of up to $72 \%$ when the seedlings were previously treated with the fungus $P$. macrosporus. Rodríguez et al. (2016) observed similar results in the control of C. gloeosporioides in coffee seedlings treated with $P$. macrosporus.

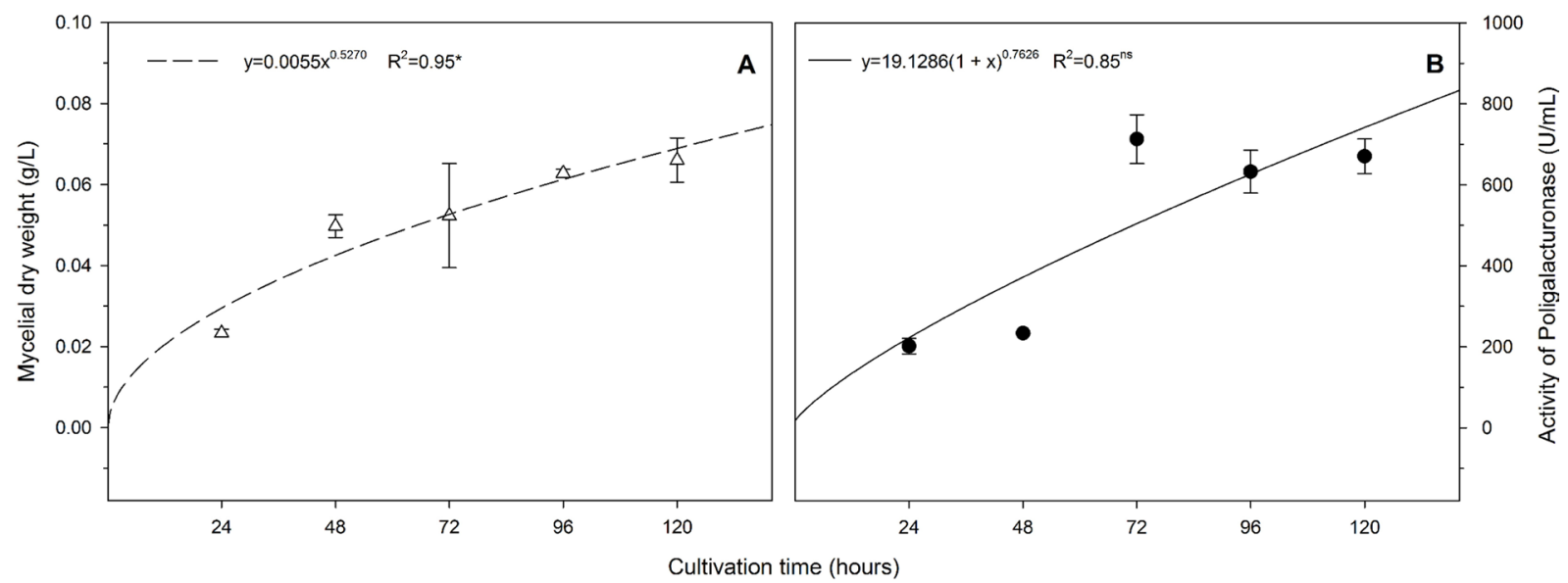

FIGURE 5 - Dry mycelial weight (A) and polygalacturonase activity in the culture supernatant (B) of Phialomyces macrosporus at $24,48,72,96$, and $120 \mathrm{~h}$ of cultivation in liquid medium with pectin. The line represents $\pm \mathrm{SE}$. *Angular coefficients differ significantly by $F$-test. 


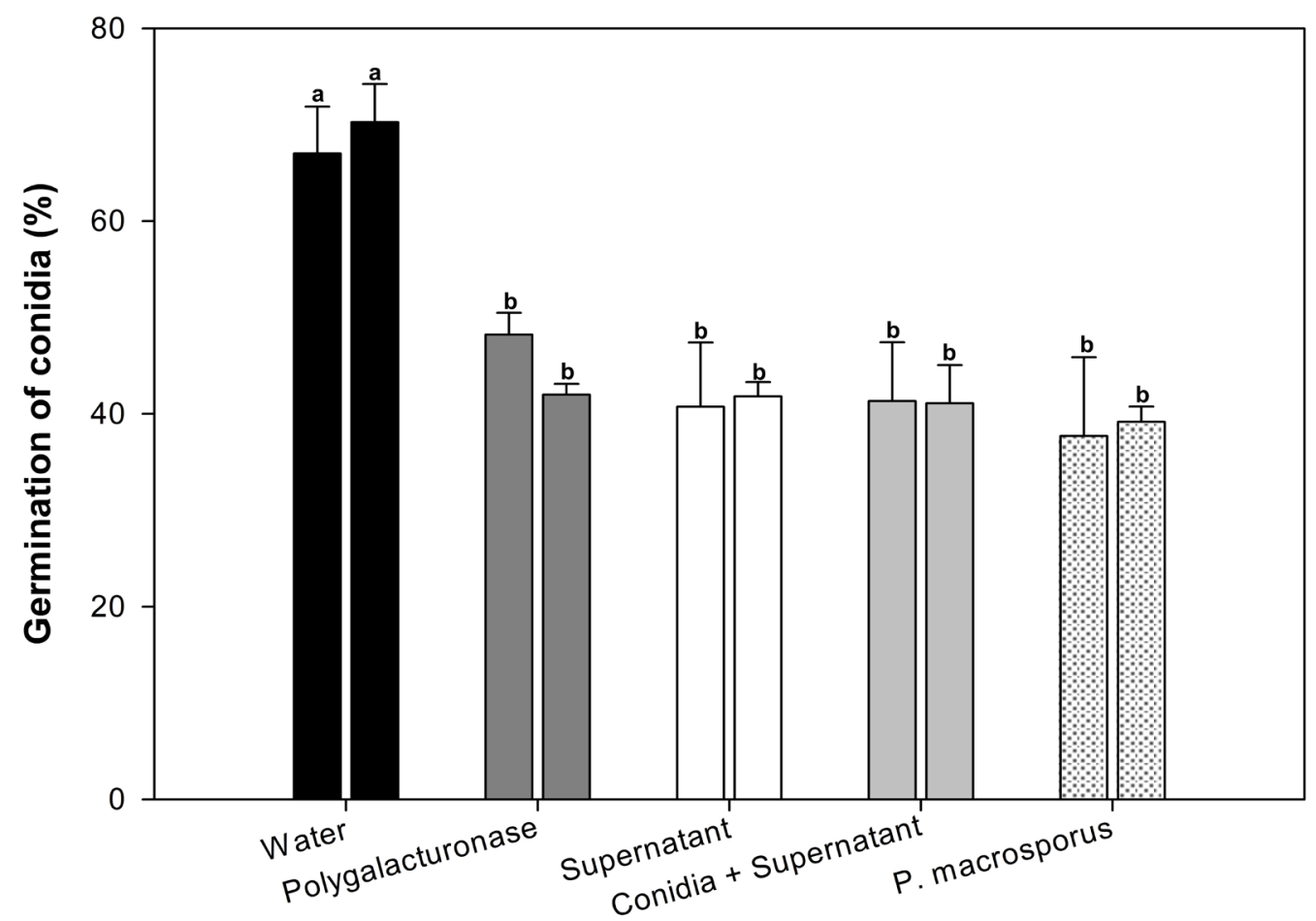

FIGURE 6 - Germination of Cercospora. coffeicola conidia after treatment with water, polygalacturonase,

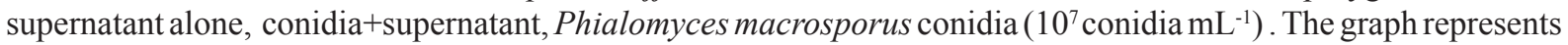
two assays conducted in different periods. The bars with the same letter are similar at the 5\% level according to Scott-Knott's multiple range test. CV $=14.48 \%$ and $12.01 \%$, respectively. The line on each bar represents \pm SE.

\section{CONCLUSIONS}

P. macrosporus inhibited $C$. coffeicola growth, sporulation and viability. P. macrosporus produced antimicrobial substances and is a promising biological agent for the integrated management of brown eye spot.

\section{ACKNOWLEDGEMENTS}

The authors would like to thank the Conselho Nacional de Ciencia e Tecnologia (CNPq) and the Coordenação de Aperfeiçoamento de Pessoal de Nível Superior (CAPES) for providing a scholarship to the authors and SISBIOTA/ FAPESP/CNPq and INCT-Café for providing financial support. We also thank Caroline Ruppert for providing an English review of the manuscript.

\section{REFERENCES}

ABE, H. et al. Total synthesis of the proposed structure of a polyketide from Phialomyces macrosporus. Chemical Communication, Murdoch, v. 51, n. 17, p. 3586-3589, Jan. 2015.
AGROFIT. Sistema de agrotóxicos Fitossanitários. Available on $:<$ http://agrofit.agricultura.gov.br/agrofit cons/principal_agrofit_cons> Accessed Nov 26, 2017.

AHMAD, R.; THARAPPAN, B.; BONGIRWAR, D.R. Impact of gamma irradiation on the monsooning of coffee beans. Journal of Stored Products Research, Amsterdam, v.39, n.2, p. 149-157. Nov. 2003.

BARAHONA, E. et al. Pseudomonas fluorescens F113 mutant with enhanced competitive colonization ability and improved biocontrol activity against fungal root pathogens. Applied and environmental microbiology, Bayreuth, v. 7, n. 77, p. 5412-5419. June 2011.

BECKMAN, P. M.; PAYNE, G. A. Cultural techniques and conditions influencing growth and sporulation of Cercosporazeae-maydis and lesion development in corn. Phytopathology, Athens, v. 73, n. 2, p. 286-289. Aug. 1983.

BELlOTTE, J. A. M. et al. Acceleration of the decomposition of Sicilian lemon leaves as an auxiliary measure in the control of citrus black spot. Tropical Plant Pathology, Brasília, v. 34, n. 2, p. 71-76. Apr. 2009. 
BOTREL, D. A. et al.Saprobic fungi as biocontrol agents of halo blight (Pseudomonas syringae pv. garcae) in coffee clones. Coffee Science, Lavras, v. 13, n. 3, p. 283 - 291, July/Sept. 2018.

CALVO GARRIDO, C. et al. Suppression of Botrytis cinerea on necrotic grapevine tissues by earlyseason applications of natural products and biological control agents. Pest management science, New Jersey, v.70, n. 4, p. 595-602. July 2014.

CARDOSO, R. M. D. L. et al. Efficiency of green manures for Cercospora leaf spot management in coffee plants. Tropical Plant Pathology, Brasília, v.38, n. 2, p. 122-127. Apr. 2013.

DE CARVALHO. et al. Modeling spatial variability and pattern of rust and brown eye spot in coffee agroecosystem. Journal of Pest Science, Berlin, v. 82, n. 1, p. 137. May 2009.

CERDA, R. et al.Primary and secondary yield losses caused by pests and diseases: Assessment and modeling in coffee. PloS onel, San Francisco v.12, n. 1, p. 133169. Jan. 2017.

FALMY, A. S. et al. Characterization of an exopoly galacturonase from Aspergillus niger. Applied Biochemestry and Biotechnology, Calgary, v.149, n. 3, p. 205-217. June 2008.

GALLETTI, S.et al. Trichoderma as a potential biocontrol agent for Cercospora leaf spot of sugar beet. BioControl, Delémont, v. 53, n. 3, p. 917-930. Sept. 2008.

GARG, G. et al. Microbial pectinases: an ecofriendly tool of nature for industries. 3 Biotech, Berlim, v. 6, n. 47, p. 1-13. Feb. 2016.

HAUPTMAN, T. et al. Application of fungicides and urea for control of ash dieback. Journal of Biogeosciences and Forestry, Basilicata, v.8, n. 2, p. 1-7. Aug. 2015.

HIRADATE, S. et al. Mulberry anthracnose antagonists (iturins) produced by Bacillus amyloliquefaciens RC2. Phytochemistry, San Diego, v.61, n. 6, p. 693-698. Nov. 2002.

KÖHL, J. et al. Effect of interrupted leaf wetness periods on suppression of sporulation of Botrytis-allii and Botrytis-cinerea by antagonists on dead onion leaves. European Journal of Plant Patholology, Utrecht, v.101, n. 6, p. 627-637. Nov. 1995.
KÖHL, J. et al. Stepwise screening of microorganisms for commercial use in biological control of plantpathogenic fungi and bacteria. Biol Control, Delémont, v.57, n. 1, p. 1-12. Apr. 2011.

LIN, Y. et al. Priority colonization of Cinnamomum camphora litter by endophytes affects decomposition rate, fungal community and microbial activities under field conditions. Pedobiologia, Jena. v. 58, n. 6, p. 177 185. Nov. 2015.

MATIELlO, J. B. et al. Cultura de café no Brasil: manual de recomendações. Edição 2010. Rio de Janeiro: MAPA: Procafé; Varginha: Fundação Procafé, 2010.

MINUSSI, R. C. et al. Sugar-cane juice induces pectin lyase and polygalacturonase in Penicillium griseoroseum. Revista de microbiologia, São Paulo, v. 29, n. 4, p. 246-250. Dec. 1998.

ODILE, C.; DANIEL, R.; DAVID-MATHIEU, T. Effect of Microsphaeropsisochracea on production of sclerotia-borne and airborne conidia of Botrytis squamosal. Biocontrol, Delémont, v. 51, n. 1, p. 107126. Feb. 2006.

PRASAD, B. N., KUMAR, M.R. Effect of non-volatile compounds produced by Trichoderma spp. on growth and sclerotial viability of Rhizoctonia solani, incitant of sheath blight of rice. Indian Journal of Fundamental and Applied Life Science, Rajasthan v.1, n. 2, p. 3742. June 2011.

REZENDE, E. F. et al Potencial enzimático e toxigênico de fungos isolados de grãos de café. Coffee Science, Lavras, v. 8, n. 1, p. 69-77, Mar. 2013.

RODRÍGUEZ, G.A.A. et al. Phialomyces macrosporus decreases anthracnose severity on coffee seedlings by competition for nutrients and induced resistance. Biological Control, Amsterdam, v. 103, v.1. n. 119128. Dec. 2016.

SIRINUNTA, A., AKARAPISAN, A. Screening of Antagonistic Bacteria for Controlling Cercospora coffeicola in Arabica Coffee. Journal of Agricultural Technology, Tehran v.11, n. 5, p. 1209-1218. July 2015.

SOUZA, A. G. C., MIZUBUTI, E.S.G., MAFFIA, L.A. Esporulação in vitro de Cercospora coffeicola. Fitopatologia Brasileira, Brasília, v.30, n 116. June 2005.

THRANE, C.; JENSEN, D.F.; TRONSMO, A. Substrate colonization, strain competition, enzyme production in vitro, and biocontrol of Pythium ultimum by Trichoderma spp. isolates P1 and T3. European Journal of Plant Pathology, Utrecht, v.106, n. 3, p. 215-225. Mar. 2000. 
ZAMBOLIM, L.; VALE, F. X. R.; ZAMBOLIM, E. M. Doenças do cafeeiro (C.arabica e C. canephora). In: KIMATI, H.; AMORIM, L.; BERGAMIN FILHO, A (Ed.), Manual de fitopatologia: doenças das plantas cultivadas. São Paulo: Agronômica Ceres Ltda, 2016. 193 p.
ZHANG, X. Antibiosis functions during interactions of Trichoderma afroharzianum and Trichoderma gamsii with plant pathogenic Rhizoctonia and Pythium. Functional and Integrative genomics, Berlin, v.15, n. 5, p. 599-610. Sept. 2015. 